\title{
The conflict between market competition and worker solidarity: moving from consumer to a citizen welfare standard in competition law
}

\author{
Firat Cengiz ${ }^{* \dagger}$ (D) \\ School of Law and Social Justice, University of Liverpool, Liverpool, UK \\ *Author email: firat.cengiz@liverpool.ac.uk
}

(Accepted 1 July 2020)

\begin{abstract}
This paper critically investigates the law and economics of competition law enforcement in conflicts between workers and employers in the EU and the US. The conflict between worker solidarity and market competition attracts significant public attention due to the legal conundrum facing precariously employed gig workers. This paper reveals that in light of the strict consumer welfare standard underlying competition rules, competition law has become an overall disciplining mechanism impeding collective worker action beyond the limited case of the gig economy. Using a holistic theoretical framework comprising of neoclassical and Marxist exploitation theories, the paper shows that sound economic analysis justifies resolving the competition-solidarity conflict in favour of solidarity. After showing that the consumer welfare standard overlooks the idiosyncratic qualities of labour as a 'fictitious' commodity, the paper offers an original and inclusive 'citizen welfare' standard that takes into consideration how anti-competitive behaviour affects workers as well as consumers. As a result, the paper also contributes to the post- 2008 debate on whether and how competition law could contribute to equality by shedding light on competition law's treatment of workers and their welfare.
\end{abstract}

Keywords: EU and competition law; collective worker action; law and economics

\section{Introduction}

This paper offers a critical investigation of the law and economics of competition law enforcement in conflicts between workers and employers in the European Union (hereinafter EU) and the US. In such cases competition law comes into direct conflict with the principle of worker solidarity: according to the principle of market competition individuals are expected to take independent economic decisions and actions, whereas workers need to take collective economic actions and decisions to protect their interests. This conflict is particularly obvious in the context of the so-called gig economy, ${ }^{1}$ in which employers keep casualised workers at legal arms' length to reduce labour and regulatory costs. ${ }^{2}$ If gig

\footnotetext{
${ }^{\dagger}$ The research underlying this paper is funded by a European Union Marie-Curie Career Integration Grant (FP7-334322). I am grateful to the participants of Critical Approaches to Competition Conference (2018, Liverpool) and Padraig McAuliffe for comments on earlier drafts of this paper. All errors remaining are mine.

${ }^{1}$ The gig economy is characterised by online platforms provided by multinational corporations where consumers meet independent service suppliers who work freelance on the basis of short-term contracts. See BY Thompson 'Digital nomads: employment in the online gig economy' (2018) 11 Journal of Culture, Politics and Innovation 1.

${ }^{2} \mathrm{D}$ Schiek and A Gideon 'Outsmarting the gig-economy through collective bargaining - EU competition law as a barrier to smart cities?' (2018) 32 International Review of Law, Computers And Technology 275; WJ Tronsor 'Unions for workers in the gig economy: time for a new labor movement' (2018) 69 Labor Law Journal 181; M Steinbaum 'Antitrust, the gig economy and labor market power' forthcoming in Law and Contemporary Problems, available at https://papers.ssrn.com/sol3/

(c) The Author(s), 2020. Published by Cambridge University Press. This is an Open Access article, distributed under the terms of the Creative Commons Attribution licence (http://creativecommons.org/licenses/by/4.0/), which permits unrestricted re-use, distribution, and reproduction in any medium, provided the original work is properly cited.
} 
workers take collective action against their working conditions, they might face attack from competition law, because legally they might be considered independent service providers, rather than workers. ${ }^{3}$

The legal conundrum facing gig workers has become an increasingly popular subject in the law and economics literature. ${ }^{4}$ Nevertheless, the more fundamental question of how the enforcement of competition rules affects the overall position of workers beyond the limited case of the gig economy remains largely unexplored. This paper aims to investigate this broader and more fundamental question. In order to provide a sufficiently global answer, the paper focuses on the legal positions of the EU and US, as the leading competition law jurisdictions and primary competition policy exporters. ${ }^{5}$ The EU-US comparison shows that despite the slightly different legal tests applied in these polities, competition rules constitute nearly equally disciplining mechanisms against collective worker action on either side of the Atlantic.

This paper also makes an original contribution to the emerging debate on whether and how competition law can contribute to wealth equality between citizens in the post-2008 crisis economy. The existing debate on the competition law-equality relationship takes the 'consumer welfare' standard as its main reference point: it focuses exclusively on the distribution of wealth between consumers and producers; as a result, it overlooks the production process that takes place before consumers meet products and services, and the position of workers within it. ${ }^{6}$ This is a natural result of competition law's reliance on a limited area of neoclassical economics called 'equilibrium economics' that understands efficiency exclusively as a market mechanism in which the price manifests itself where supply meets demand. ${ }^{7}$ Departing from the mainstream competition law and economics methodology, this paper builds its investigation on a holistic theoretical foundation, looking beyond equilibrium economics at labour exploitation theory as established in neoclassical as well as Marxian models. This analysis shows that despite standing at opposing ends of the political spectrum and whilst having some fundamental differences, Marxist and neoclassical models agree that collective worker action is economically beneficial and socially necessary. As a result, a critical analysis of the current legal situation on both sides of the Atlantic in light of this holistic framework illustrates how competition law's hostility towards collective worker action is not only unjust but also economically unsound.

This paper demonstrates that the key problem in competition law's treatment of labour stems from the application of the consumer welfare standard in cases involving the competition-solidarity conflict without paying any attention to the idiosyncratic qualities of labour that render it naturally open to exploitation. Similarly, the consumer welfare standard overlooks the fact that consumers and workers are essentially the same group of people and one's welfare cannot be increased or decreased without affecting the other's. ${ }^{8}$ Even if worker exploitation could result in reduced labour costs and decreased prices, this cannot be deemed efficient as it reduces the workers' welfare and results in broader

Papers.cfm?abstract_id=3347949 (last accessed 29 July 2020); M Lao 'Workers in the "gig" economy: the case for extending the labor exemption' (2018) 51 UC Davis Law Review 1543. See also EA Posner et al 'Antitrust remedies for labor market power' (2018) 132 Harvard Law Review 536 looking specifically at the position of labour in merger cases.

${ }^{3}$ The specific question of whether collective worker action in the gig economy would be considered a violation of competition law is yet to be clarified by the courts and competition authorities on both sides of the Atlantic. See Tronsor, above $\mathrm{n} 2$, at 185; Lao, above $\mathrm{n} 2$, at 1553. See Chamber of Commerce of the USA $v$ City of Seattle, 890 F 3d 769 (9 ${ }^{\text {th }}$ Cir 2018) in which the federal court found a local legislation supporting collective action by gig workers against federal antitrust law in light of the state action doctrine without discussing the legal position of gig workers under federal antitrust law. See also J Prassl Humans as a Service: The Promise and Perils of Work in the Gig Economy (Oxford: Oxford University Press, 2018).

${ }^{4}$ Tronsor, above n 2; Schiek and Gideon, above n 2; M Ford and A Bogg 'Between statute and contract: who is a worker?' (2019) 135 Law Quarterly Review 347; The University of Oxford, 'The employment status of Uber drivers', 2017, available at http://ohrh.law.ox.ac.uk/wordpress/wp-content/uploads/2018/02/5.-Uber.pdf (last accessed 29 July 2020).

${ }^{5}$ See D Gerber Global Competition: Law, Markets and Globalisation (Oxford: Oxford University Press, 2012) p 273.

${ }^{6}$ See further in the following section, text to $\mathrm{n} 13 \mathrm{ff}$.

${ }^{7} \mathrm{H}$ Buch-Hansen and A Wigger 'Revisiting 50 years of market-making: the neoliberal transformation of European competition policy' (2010) 17 Review of International Political Economy 20.

${ }^{8}$ This is further explained in the next section of the paper as well as in the fourth section proposing the citizen welfare approach. 
negative socio-economic effects. Similarly, collective worker action resulting in higher labour costs and potentially higher prices cannot automatically be deemed inefficient, because although this might increase the prices consumers pay, they benefit from higher wages and better working conditions in their position as workers. As a result of this critical analysis, the paper proposes an original and more inclusive 'citizen welfare' standard that takes into account the economic effects of anti-competitive behaviour on workers as well as consumers. The citizen welfare standard could also potentially be applied in other contexts to solve long-standing conflicts between competition and other policy objectives, such as industrial, environmental and social policy objectives, ${ }^{9}$ although this paper primarily focuses on the application of citizen welfare to the competition-solidarity conflict.

The structure of the paper is as follows: the next section provides an opening discussion of competition law, consumer welfare and equality. This is followed by a discussion of the economic theory of labour exploitation. Then, the paper investigates how competition law approaches the competitionsolidarity conflict in the EU and the US. The fourth section critically discusses the EU and US legal positions in light of economic theory. This section also develops the citizen welfare approach as an alternative to consumer welfare for the resolution of the competition-solidarity conflict. This is finally followed with conclusions. Regarding terminology, this paper uses the term 'worker' (rather than employee) as a non-legal, generic term encompassing all individuals who make a living by providing labour power as a production factor in the production process of goods and services. Similarly, the term 'labour' is used to refer to the contribution of the workers to the production process as an abstract human factor. However, if the courts or authorities in question use a different term (such as employee) in a specific case, the paper uses the same term in the discussion of that specific case.

\section{Problematising the competition-solidarity conflict: competition law, consumer welfare and equality}

The enforcement of competition rules present courts and competition authorities with increasingly complex problems in the context of the fundamental state versus the market dichotomy underlying neoclassical economics. ${ }^{10}$ On the one hand, courts and state authorities need to intervene and enforce competition rules in cases where economic agents diverge from equilibrium economics. Equilibrium economics presumes that price and output materialise at the exact point where demand meets supply. ${ }^{11}$ On the other hand, the intrusion of courts and state authorities using competition law must be minimal and precisely target those proven cases of explicit divergence from equilibrium economics, because neoclassical economics considers the state's intrusion to equilibrium economics to be at least as harmful as the divergence of economic agents from it. ${ }^{12}$ The overarching objectives of competition law play a fundamental role in guiding courts and competition authorities towards behaviour that is accepted as being in conflict with equilibrium economics in light of neoclassical principles.

In the US since the prominence of the Chicago and post-Chicago Schools, there is agreement within the mainstream competition law and economics scholarship that economic efficiency and consumer welfare constitute the primary objectives of competition law. ${ }^{13}$ In this regard, competition rules

\footnotetext{
${ }^{9}$ See eg AC Witt 'Public policy goals under EU competition law - now is the time to set the house in order' (2012) 8 European Competition Journal 443.

${ }^{10} \mathrm{C}$ Donnaruma and N Partyka 'Challenging the presumption in favor of markets' (2012) 44 Review of Radical Political Economics 40.

${ }^{11} \mathrm{M}$ Watson The Market (Newcastle: Agenda, 2018) p 61.

${ }^{12} \mathrm{RH}$ Bork The Antitrust Paradox (New York: The Free Press, 1993); RA Posner 'A statistical study of antitrust enforcement' (1970) 13 The Journal of Law and Economics 365; MP Schinkel and J Tuinstra 'Imperfect competition law enforcement' CeNDEF Working Paper No 04-07, available at https://papers.ssrn.com/sol3/papers.cfm?abstract_id=366420 (lase accessed 27 July 2020).

${ }^{13}$ AI Gavil et al Antitrust Law in Perspective (Maine: West Academic Publishing, 2002) p 17; M Motta Competition Policy, Theory and Practice (Cambridge: Cambridge University Press, 2009) p 9.
} 
need to target those economic activities that are proven to reduce efficiency and/or result in consumer harm, for instance in the form of increased prices or reduced output and quality. ${ }^{14}$ Whilst being influenced by ordoliberal ideals of economic freedom in its inception, EU competition law has also moved into a similar neoclassical dimension following the reform of competition laws advocated by the European Commission since the late 1990s with the motto of a 'more economic approach'. ${ }^{15}$ The reform of competition rules in the EU took place against a backdrop of the general entrenchment of the policy objectives of efficiency and minimal state intervention to the economy advocated by the Lisbon and the Europe 2020 Agendas. ${ }^{16}$

Particularly since the 2008 financial and economic crisis, the legitimacy and accuracy of neoclassical economics as well as those of policies that take equilibrium economics as their underlying foundation have been increasingly questioned. Under the shadow of rapidly increasing inequality, particularly after the most recent economic and financial crisis, political economists increasingly argue that policies' legitimacy should not be measured only by their contribution to economic growth and efficiency but also to equality and other common goods, such as health and wellbeing of citizens. ${ }^{17}$ Competition law has also been a subject in this debate. Among others, Nobel prize-winning Keynesian economist Joseph Stiglitz openly called for a more aggressive competition policy targeting monopolies and cartels with a view to increasing wealth equality. ${ }^{18}$ Within competition law scholarship it has been argued that competition law could be utilised to decrease inequality, for instance by taking strong action against anti-competitive behaviour that causes harm to the most vulnerable consumers or those with the lowest disposable income, such as anti-competitive practices in food retail markets. ${ }^{19}$ According to the opposite view, competition law is not equipped with the right tools to tackle inequality, as this is not competition law's primary purpose; thus, decreasing inequality should be left to redistributive tax and social policies which are fit for this purpose. ${ }^{20}$

Nevertheless, the debate on competition law and equality still takes neoclassical economic principles as the main reference point, which is paradoxical given that it is those principles that are primarily responsible for the increasing levels of inequality in the first place. As a result, the debate suffers from two fundamental weaknesses: first, equality between citizens is not perceived as a public good and an objective on its own but it is considered useful and necessary to the extent that it contributes to economic growth. ${ }^{21}$ Secondly, whether or not competition law and policy actually or potentially contribute to equality is discussed within the limits drawn by neoclassical principles; and the wealth distribution relationship is perceived as exclusively between producers and consumers. As a result, the entire production process that products and services go through before they are placed on the market is completely overlooked. With producers and consumers perceived as the only groups of individuals potentially affected by the enforcement of competition rules as parties to the equality relationship, workers who create goods and services utilising their labour power are absent in the debate. This also overlooks the fact that in complex modern societies, individuals have multiple overlapping social

\footnotetext{
${ }^{14} \mathrm{~A}$ Foer 'On the inefficiencies of efficiency as the single-minded goal of antitrust' (2015) 60 The Antitrust Bulletin 103; EM Fox 'The efficiency paradox' in R Pitofsky (ed) How the Chicago School Overshot the Mark: The Effect of Conservative Economic Analysis on US Antitrust (New York: Oxford University Press, 2008) pp 77-99.

${ }^{15}$ AC Witt The More Economic Approach to EU Competition Law (Oxford: Hart Publishing, 2016).

${ }^{16}$ Buch-Hansen and Wigger, above n 7; F Cengiz 'Legitimacy and multi-level governance in European Union competition law: a deliberative discursive approach' (2016) 54 Journal of Common Market Studies 826 at 832-834.

${ }^{17} \mathrm{G}$ Standing A Precariat Charter (London: Bloomsbury, 2014) pp 58-61; JE Stiglitz The Price of Inequality (New York: WW Norton \& Co, 2012); P Krugman End The Depression Now (New York: WW Norton \& Co, 2013) pp 70-77.

${ }^{18} \mathrm{JE}$ Stiglitz 'Towards a broader view of competition policy' Roosevelt Institute Working Paper, June 2017, available at www8. gsb.columbia.edu/faculty/jstiglitz/sites/jstiglitz/files/Towards\%20a\%20Broader\%20View\%20of\%20Competition\%20Policy\%20 Roosevelt\%20Working\%20Paper.pdf (last accessed 27 July 2020).

${ }^{19}$ JB Baker and SC Salop 'Antitrust, competition policy, and inequality' (2015) 104 The Georgetown Law Journal Online 1. See also L Khan and S Vahesaan 'Market power and inequality: the antitrust counterrevolution and its discontents' (2017) 11 Harvard Law and Policy Review 235.

${ }^{20}$ DA Crane 'Antitrust and wealth inequality' (2016) 101 Cornell Law Review 1171.

${ }^{21}$ Baker and Salop, above n 19; Crane, ibid.
} 
and economic roles and identities: most importantly for the purposes of this paper, as will be discussed in the next section, most consumers are also workers. Thus, the overall economic effect of competition law on equality will be negative or neutral at very best if the welfare of consumers increases as a result of a reduction in the welfare of workers.

\section{Labour exploitation in Marxian and neoclassical economics}

Both Marxian and neoclassical economics accept that there are social and economic reasons to treat labour differently from other commodities and to not subject labour to simple cost-benefit analyses. As a major difference between the two approaches, Marxian economics perceives the exploitation of workers as a problem of markets, whereas neoclassical economics sees it as a problem in markets. Accordingly, the former proposes the abolition of class relationships underlying the market mechanism altogether, whereas the latter finds solutions within the market which would tilt the balance of power in the workers' favour. Nevertheless, the idiosyncratic qualities of labour as specified not only in Marxian but also neoclassical exploitation theories imply that there are fundamental social and economic reasons for protecting collective worker action as a matter of common good, although this may come into direct conflict with the principle of market competition.

Marxian approaches perceive the exploitation of workers as a natural result of the class relationships between capitalists and workers underlying the production processes of goods and services. According to Marxian economics, working classes who do not enjoy access to the capital necessary for the production of goods and services need to surrender their labour power to the capitalist in order to survive. This is necessarily a relationship of exploitation by its nature because the surplus value created by the worker during the process of production belongs to the capitalist. ${ }^{22}$ It cannot be argued that the worker enjoys the freedom to choose to surrender his labour power, since as long as they do not enjoy access to capital, the workers' choice is merely to surrender labour power to one capitalist or another. ${ }^{23}$ Alternatively, they can return to the 'reserve army' of precariousness from which the capitalist can choose another worker. ${ }^{24}$

Marxian economics does not perceive the relationship of exploitation from a moral perspective: capitalists do not exploit workers because they are evil, but rather because they are subject to the disciplining forces of the capitalist market competition. Under those forces, the primary incentive of each capitalist is to continue the process of so-called capitalist accumulation with the eventual aim of reaching a monopoly position. ${ }^{25}$ In the shadow of the same forces, capitalists force workers to increase their productivity so that the production costs of each individual capitalist are lower than their competitors'. This means that, as the competitive process intensifies, the worker surrenders more and more of the surplus value, increasing the rate of exploitation. ${ }^{26}$ This 'cheapening' of labour, however, is not necessarily more 'efficient' in the neoclassical sense, because it creates a social cost consisting of detriments to the health and wellbeing of the working class and society as a whole that is not borne by the capitalist. ${ }^{27}$ Empirical studies confirm that labour exploitation has consistently intensified since the 1950s: whilst production processes have become increasingly more productive, contributing to larger profits, the wages paid to workers have continuously decreased. ${ }^{28}$

\footnotetext{
${ }^{22} \mathrm{~K}$ Marx Capital, Volume I (London: Wordsworth, 2013) p 120; M Heinrich An Introduction to the Three Volumes of Karl Marx's Capital (New York: Monthly Review Press, 2004) p 81.

${ }^{23} \mathrm{G}$ Palermo 'The economic debate on power: a Marxist critique' (2014) 21 Journal of Economic Methodology 175 at 188; G Palermo 'Competition: a Marxist view' (2017) 41 Cambridge Journal of Economics 1559 at 1569.

${ }^{24} \mathrm{RJ}$ Jonna and J Foster 'Marx's Theory of Working-Class Precariousness' (2016) 67 Monthly Review, available at https:// monthlyreview.org/2016/04/01/marxs-theory-of-working-class-precariousness/ (last accessed 27 July 2020).

${ }^{25}$ Marx, above n 22, p 395; Heinrich, above n 22, p 108.

${ }^{26}$ Marx, above n 22, p 425 .

${ }^{27}$ A Wigger and H Buch-Hansen 'Competition, the global crisis and alternatives to neoliberal capitalism: a critical engagement with anarchism’ (2013) 35 New Political Science 604 at 608.

${ }^{28}$ Steinbaum, above n 2, p 7.
} 
As argued by Karl Polanyi, labour constitutes a so-called fictitious commodity. ${ }^{29}$ This is because the labour power provided by the worker is attached to and inseparable from the human. Unlike other commodities, workers are not produced with the aim of being exchanged in the market for profit. As a result, the argument for self-regulating markets and for equilibrium economics predicting that price (ie wage) materialises where supply meets demand loses all credibility when it comes to labour. Polanyi argues that:

For the alleged commodity 'labour power' cannot be shoved about, used indiscriminately, or even left unused without affecting also the individual who happens to be the bearer of this peculiar commodity. In disposing of a man's labour power the system would, incidentally, dispose of the physical, psychological, and moral entity 'man' attached to that tag. ${ }^{30}$

Whilst being considered as part of the classical, rather than Marxian, political economy, Amartya Sen's capability-based equality framework ${ }^{31}$ also supports the perception of labour as a fictitious commodity. In the context of this framework, work is considered not only as paid labour which is necessary for one's economic survival, but also as a capability that is essentially connected to one's socio-economic as well as physical and mental well-being. When carried out as a self-determined, self-realising activity, work contributes to a satisfactory and dignified life. ${ }^{32}$

In light of Marxian economics, workers and consumers belong to one and the same group of people from a class perspective. This is exemplified in the Marxian theory of labour fetish. ${ }^{33}$ According to this, the real producers of products, in other words workers, come into contact with the result of the production process embodying their labour power only in the market. The market system creates a highly complex web of exchange relations rendering it impossible for workers to see either their individual role or those of other workers in the production process, which is now concealed in the exchange value of the product. ${ }^{34}$ This also means that what should normally be a social relationship between individuals turns into a materialistic relationship between things, because workers connect with each other through the exchange relationship in the market. As argued by Marx:

... the producers do not come into social contact with each other until they exchange their products, the specific social character of each producer's labour does not show itself except in the act of exchange. In other words, the labour of the individual asserts itself as a part of the labour of society, only by means of the relations which the act of exchange establishes directly between the products, and indirectly, through them, between the producers. ${ }^{35}$

Neoclassical economics also acknowledges that due to its idiosyncratic qualities labour is naturally open to exploitation. Although without using the term 'exploitation', Adam Smith argued that employers would be likely to enter into collusion to keep wages down when the bargaining power tilts in favour of workers; and he also suggested that the provision of labour in advanced societies necessarily involves an unfair element, because the provider of labour does not share the result of the labour with the master. ${ }^{36}$ Similarly, Alfred Marshall argued that labour was open to exploitation by its nature because it is highly perishable (meaning that the economic value of any time that labour

\footnotetext{
${ }^{29} \mathrm{~K}$ Polanyi The Great Transformation (Boston: Beacon Press, 2001) p 76.

${ }^{30}$ Polanyi, ibid. See also J Paton 'Labour as a (fictitious) commodity: Polanyi and the capitalist "market economy"' (2010) 21 The Economic and Labour Relations Review 77.

${ }^{31}$ A Sen Inequality Re-examined (Cambridge: Harvard University Press, 1992).

${ }^{32}$ FE Düzenli 'Surplus-producing labour as a capability: a Marxian contribution to Amartya Sen's revival of classical political economy' (2016) 40 Cambridge Journal of Economics 1019.

${ }^{33} \mathrm{~S}$ Knafo 'The fetishizing subject in Marx's Capital' (2002) 26 Capital \& Class 145.

${ }^{34}$ D Harvey A Companion to Marx's Capital (London: Verso, 2013) p 40.

${ }^{35}$ Marx, above n 22, p 48.

${ }^{36}$ A Smith Wealth of Nations (London: Ward, Lock \& Co, 1893) pp 52, 56 and 64.
} 
is withheld will be lost forever); and that workers do not have access to reserve funds to enable them to withhold their labour power until the conditions for its supply are advantageous. ${ }^{37}$

Nevertheless, it was Arthur Pigou who developed the neoclassical theory of labour exploitation. According to Pigou, if wages are below marginal net product (ie the resulting change in output when one more worker is employed) the wage relationship between the worker and the employer should be deemed exploitative. ${ }^{38}$ In neoclassical theory, exploitation takes place because workers fail to switch jobs as quickly as they should when responding to a decrease in wages; in other words, it takes place because the price elasticity of labour is less than perfect. ${ }^{39}$ In more recent models, exploitation is also explained with workers' and employers' asymmetrical experience of frictions. Unless the individual worker or the specific group of workers in question can offer a highly valued skill that is in low supply, it is less costly for employers to change workers than it is for workers to switch jobs. As a result, in general, employers enjoy stronger bargaining power than workers. Overall, empirical studies show that labour is paid substantially less than its marginal product. ${ }^{40}$ Key reasons for this are problems facing organised and collective worker action, ignorance, heterogeneous preferences and mobility costs. ${ }^{41}$ For instance, in the US between the 1940s and the 1950 s when the majority of workers belonged to a union, the income inequality was at its lowest. ${ }^{42}$

Unlike Marxian theory, neoclassical theory does not see labour exploitation as a direct result of class relations. Nevertheless, neoclassical theory perceives exploitation as unfair by its very nature, because on the one hand workers receive wages that are less than their contribution to the revenue of the employer, and on the other hand, the employer makes a profit that is the direct result of the labour of the worker. ${ }^{43}$ Additionally, similar to the Marxian theory, neoclassical theory sees a direct relationship between competition and the level of exploitation. To begin with, the worker-employer relationship is one of bilateral monopoly which gives the employer considerable power as the monopsonist buyer of the labour power. ${ }^{44}$ Additionally, the larger the market power of the employer, the stronger will be the bargaining power against the worker because there will be fewer other work alternatives for the worker to switch to. ${ }^{45}$ Nevertheless, extensive competition could also result in super-exploitation because employers would be under immense pressure to keep their production costs down. ${ }^{46}$

Notwithstanding the fact that the Marxian model views worker exploitation as a problem of markets and the neoclassical model sees it as a problem in markets, both perceive labour as fundamentally different from commodities and highly open to exploitation due to its idiosyncratic characteristics. Thus, it could be concluded that beyond the limited field of equilibrium economics, economic theories from different ends of the political spectrum agree that there are fundamental social and economic reasons to protect worker solidarity and collective action as a matter of common good.

\section{The competition-solidarity conflict in the EU and the US}

This section of the paper critically investigates how competition law approaches the competitionsolidarity conflict in the EU and the US. In both polities, it is possible for employers to rely on

\footnotetext{
${ }^{37}$ A Marshall Principles of Economics (London: Macmillan, 1920) p 471.

${ }^{38}$ AC Pigou The Economics of Welfare (New York: Macmillan, 1923) p 549.

${ }^{39}$ Pigou, ibid, p 557; see also J Robinson Economics of Imperfect Competition (London: Macmillan, 1933) p 282.

${ }^{40}$ J Persky and H Tsang 'Pigouvian exploitation of labour' (1974) 56 The Review of Economics of Statistics 52 at 52.

${ }^{41}$ A Manning Monopsony in Motion: Imperfect Competition in Labor Markets (Princeton: Princeton University Press, 2005) p 4.

${ }^{42}$ Tronsor, above n 2, at 182 .

${ }^{43} \mathrm{D}$ Coldwell 'Pure neoclassical exploitation and the level of wages' (1990) 49 American Journal of Economics and Sociology 21 at 27.

${ }^{44}$ Manning, above n 41, p 4. See also WM Boal and MR Ransom 'Monopsony in the labor market' (1997) 35 Journal of Economic Literature 86.

${ }^{45}$ Persky and Tsang, above $\mathrm{n} 40$, at 57.

${ }^{46}$ Pigou, above n 38, p 560.
} 
competition rules to prevent effective collective action by workers. Also, in both polities, workers can invoke competition rules against collusive employer behaviour, such as those suppressing wages and other working conditions. Nevertheless, although it is theoretically and legally possible to initiate the latter type of action in the EU, there has not been an example of competition rules being enforced against collusive employee behaviour at the EU level. This might be due to a few alternative factors, such as nationally segregated labour markets, which do not trigger EU jurisdiction; lack of knowledge and resources of labour organisations to raise the issue at the EU level; or simply the absence of crossborder employer collusion. The first sub-section below looks into actions brought by employers against workers in the EU, followed by discussions of actions against workers and employers in the US respectively, as well as a brief comparison of the legal position on both sides of the Atlantic.

\section{(a) Competition law against workers in the EU}

EU competition rules that are relevant to worker-employer conflicts are set forth in Articles 101 and 102 of the Treaty on the Functioning of the European Union (TFEU), which, respectively, prohibit anti-competitive agreements and abuses of dominance. In order to be a subject of EU competition rules, the legal or natural person in question needs to be an 'undertaking'. This is a generic EU law concept that does not overlap with any specific legal or economic category of entities. The 'undertaking' covers anyone, including companies and legal persons, who provides goods and services in the market in competition with others notwithstanding their individual motives and goals in doing so. ${ }^{47}$ Thus, one key question that needs to be addressed in order to determine whether EU competition law could apply to collective worker action is whether workers and organisations representing their interests constitute 'undertakings' as defined in EU competition law. If the answer to this question is yes, then a second question that needs to be addressed is what kind of a solution, if any, EU law and in particular Treaty provisions, which envisage different social and economic policy goals, offer for the resolution of the competition-solidarity conflict. This is the legal landscape that the EU courts navigated through whilst constructing a fragile and imprecise judge-made labour exemption to the enforcement of competition rules. ${ }^{48}$

Albany ${ }^{49}$ was the first case in which the Court of the Justice of the European Union faced a question regarding the enforcement of competition rules against collective worker action. The Dutch pension regime set low compulsory contributions to worker pension funds. In order to address this, worker and employer unions signed a collective agreement, which established compulsory complementary pension contributions to be paid to and managed by a single provider. This system was built on the principle of solidarity so that individual employers could not seek lower contributions for low-risk workers, which could eventually push the high-risk workers out of the pension scheme. Albany argued that the scheme was anti-competitive, as it did not allow employers to access other pension schemes offered by competing providers in the market.

Whilst considering whether the compulsory pension scheme was anti-competitive, the Court first observed that the Treaty not only envisaged establishing 'a system ensuring that competition in the internal market is not distorted' but also the promotion of 'a harmonious and balanced development of economic activities' and 'a high level of employment and social protection'. ${ }^{50}$ After evaluating the social and economic policy objectives envisaged in the Treaty, the Court came to the conclusion that:

It is beyond question that certain restrictions of competition are inherent in collective agreements between organisations representing employers and workers. However, the social policy objectives

\footnotetext{
${ }^{47}$ See eg C-159 and 160/91, Christian Poucet v Assurances Générales de France and Caisse Mutuelle Régionale du Languedoc-Roussillon, ECLI:EU:C:1993:63; C-41/90, Klaus Höfner and Fritz Elser v Macrotron GmbH, ECLI:EU:C:1991:161.

${ }^{48} \mathrm{~S}$ McCrystal and P Syrpis 'Competition law and worker voice' in A Bogg and T Novitz (eds) Voices at Work (New York: Oxford University Press, 2014); Schiek and Gideon, above n 2.

${ }^{49} \mathrm{C}-67 / 96$, Albany International and Stichting Bedrijfspensionfonds Textielindustrie, ECLI:EU:C:1999:430.

${ }^{50}$ Previously Arts 2 and 3 EC, now addressed in Art 9 TFEU; Albany, ibid, para 5881.
} 
pursued by such agreements would be seriously undermined if management and labour were subject to [Article 101(1)] of the Treaty when seeking jointly to adopt measures to improve conditions of work and employment. ${ }^{51}$

Nevertheless, in the same case the Court also resolved the competition-solidarity conflict in favour of competition; and it decided that despite the principle of solidarity underlying it, the compulsory pension scheme in question and other similar organisations constituted 'undertakings' in the eyes of EU competition law, because they provided a good or a service in competition with others which employers and workers would have to buy from another provider in the absence of the compulsory scheme. ${ }^{52}$ This implies that public goods offered for the wellbeing of workers, such as the pension scheme in question, are considered no different from commodities that are produced with the purpose of making profit. Additionally, the categorisation of a collective workers' organisation as an undertaking means that similar organisations could potentially be targeted by competition rules in the future if the circumstances are different. The Court repeated the same labour exemption in a few similar cases arising out of conflicts regarding compulsory pension and healthcare systems in different Member States. ${ }^{53}$ Among those cases, van der Woude was particularly important because in that case the Court made a specific reference to the fact that the agreement in question was the result of a collective bargaining process between employers and workers whilst deciding whether the labour exemption applied or not. ${ }^{54}$

In a case involving a compulsory health insurance scheme, the EFTA Court clarified the conditions of the labour exemption as: an agreement entered into under the framework of collective bargaining between workers and employers that is concluded in pursuit of the objective of improving conditions of work and employment. ${ }^{55}$ Whilst these strict conditions seemingly limit the scope of the labour exemption, in the same case the Court used vague language leaving key issues to be addressed by the national court. The Court opined that conditions of work and employment should be interpreted broadly and should include, inter alia, wages, working hours and other working conditions such as safety, the workplace environment, holidays, training and continuing education, and consultation and co-determination between workers and management. ${ }^{56}$ The Court also stated that: 'Even if individually, the provisions would not lead to any certain resolution of the status of the collective agreement in relation to the applicability of [competition rules] their aggregate effect may bring the agreement within the scope of [competition rules] ${ }^{57}$ Not only does this exceptionally vague formulation further limit the scope of the already fragile labour exemption, it does not provide any clarification or assistance to national courts in determining whether a certain type of collective labour action breaches EU competition rules.

One year after Albany, the Court faced the competition-solidarity conflict in a case involving the organisation of dockworkers in Belgium. ${ }^{58}$ The Belgian state made it illegal for employees to hire nonregistered workers, which Becu and others disregarded to lower their labour costs; and as a result, they faced criminal proceedings. In the criminal proceedings, they argued that the national law in question violated EU competition rules. In this case, the Court dealt directly with the question of whether workers qualified as 'undertakings' as individuals who sell their labour in the market in competition with other workers. The Court decided that workers did not constitute undertakings; thus, they could not

\footnotetext{
${ }^{51}$ Albany, above n 49, para 5882.

${ }^{52}$ Albany, above n 49, para 5888 .

${ }^{53}$ See C-115, 116 and 117/97, Brentjens' Handelsonderneming BV, ECLI:EU:C:1999:434; C-219/97, Maatschappij Drijvende Bokken BV, ECLI:EU:C:1999:437; C-222/98; C-437/09, AG2R Prévoyance v Beaudout Père et Fils SARL, ECLI:EU:C:2011:112.

${ }^{54}$ Hendrik van der Woude, ECLI:EU:C:2000:226.

${ }^{55}$ E-8/00, Norwegian Federation of Trade Unions, available at https://eftacourt.int/download/8-00-judgment/? wpdmdl=1744 (16 January 2020).

${ }^{56}$ Norwegian Federation of Trade Unions, ibid, pp 17-18.

${ }^{57}$ Norwegian Federation of Trade Unions, ibid, p 18.

${ }^{58}$ C-22/98, Jean Claude Becu, ECLI:EU:C:1999:419.
} 
be a subject of the EU competition rules. This significant judgment protected workers as well as the Member State's prerogative of regulating work from the potential attack of EU competition rules. Nevertheless, in the same judgment when deciding who qualifies as a 'worker', the Court placed a significant emphasis on the element of control enjoyed by employers over the worker. ${ }^{59}$ This rendered casualised individuals - who are deliberately employed subject to more flexible working conditions potentially open to attack from competition law if they attempt to take collective action against their working conditions.

In subsequent cases, the Court had to create novel categories of workers when deciding on the legal position of casualised individuals who did not fit within the strict conditions of the labour exemption. In FNV Kunsten ${ }^{60}$ the Court faced a collective agreement concluded in the Netherlands that addressed the working conditions of substitute orchestra players who did not have a regular employment relationship with orchestras. In light of the previous case-law, the agreement in question should not have benefited from competition law exemption, since it was not concluded between workers and employers. In order to protect substitute players from the attack of EU competition rules, in this case the Court observed that in today's economy it is not always easy to establish the status of selfemployed contractors as "undertakings", and it created a so-called category of false self-employed individuals whose situation is 'comparable to that of employees'. ${ }^{61}$ Nevertheless, whilst doing so the Court relied on a strict relationship of control and defined the labour exemption narrowly for the 'false self-employed' 'who... perform for an employer, under a works or service contract, the same activity as that employer's employed workers'. ${ }^{62}$

As a result of the Court's decision to treat worker organisations as undertakings in Albany, competition law became a potential disciplining mechanism against collective worker action. As a result, the Court had to formulate imprecise and generic tests in order to protect from competition law attack those individuals who, whilst not satisfying the formal criteria of workers, also do not act as undertakings providing goods and services. The FNV Kunsten test is unlikely to provide protection to casualised workers in the future, as it defines the category of 'false self-employed' using workers formally employed under a work contract as a primary reference point. Most problematically and imminently, this test will not provide any protection to gig workers, since companies operating in the gig economy rely on a service relationship, rather than an employment contract, to keep workers at arms' length and to place them in the alleged position of self-employed individuals. Since these companies do not employ any workers under an official work contract to begin with, gig workers would not fit into the Court's formulation of 'false self-employed'. As a result, ad hoc formulations of who constitutes an undertaking fail to provide a secure harbour for collective worker action. A more inclusive welfare test of what constitutes a violation of competition rules, as suggested in the next section of this paper, is necessary to achieve this end.

\section{(b) Antitrust law against workers in the US}

Competition rules - or antitrust rules as they are called in the US - that employers can invoke to attack collective worker action are codified in the Sherman Act's Sections I and II, which, similarly to EU competition rules, declare anti-competitive agreements and monopolisation to be 'conspiracies in restraint of trade'. ${ }^{63}$ Nevertheless, unlike EU competition rules, the Sherman Act does not apply to any specific group of individuals or entities. In the absence of any judicial or legislative exemption, the Sherman Act and other US antitrust rules can potentially target anyone.

The application of antitrust rules to collective worker action in the US has been subject to continuous disagreement between the Supreme Court and Congress. The Court opened collective labour

\footnotetext{
${ }^{59} \mathrm{Becu}$, ibid, para 5692.

${ }^{60} \mathrm{C}-413 / 13$, FNV Kunsten Informatie en Media $v$ Staat der Nederlanden, ECLI:EU:C:2014:2411.

${ }^{61}$ Kunsten, ibid, para 31.

${ }^{62}$ Kunsten, ibid, para 42.

${ }^{63} 26$ Stat 209, 15 USC $\$ \$ 1$ and 2.
} 
action up to antitrust attack through generous readings of the scope of antitrust rules; and when Congress attempted to protect collective labour action by enacting legal exemptions, the Court interpreted those exemptions narrowly. Similarly, the legal history and discourse of the competitionsolidarity conflict in the US is extremely political, since Supreme Court justices did not hide their personal political opinions in favour of or against collective worker action when drafting judgments or dissenting opinions. Secondary boycotts ${ }^{64}$ and collective actions in which unions collaborate with non-union actors, most notably employers, to achieve their goals, were subject to particular disagreement between the Supreme Court and Congress as well as amongst Supreme Court justices.

Soon after the entry into force of the Sherman Act in 1890, the Supreme Court decided, in the case of Danbury Hatters, ${ }^{65}$ that secondary boycotts were illegal in light of the Sherman Antitrust Act. Using particularly political language the Court defined secondary boycotts as 'a system of petty tyrannies that might be tolerated in Siberia, but could not be borne by independent Americans' ${ }^{66}$ In response, in 1914 Congress enacted the Clayton Act, which, inter alia, brought forward an extensive labour exemption in sections 6 and 20. ${ }^{67}$ The political position of Congress in favour of collective worker action was particularly obvious from the wording of section 6, which declared that: 'The labor of a human being is not a commodity or article of commerce. ${ }^{68}$ Section 6 further declared that antitrust laws should not forbid the existence and operation of worker organisations instituted for the purposes of mutual help and their members from pursuing the legitimate objectives of such organisations.

According to the Senate debate, the purpose of this law was to remove all doubt that worker organisations were not within the scope of the antitrust laws. ${ }^{69}$ Using language akin to Karl Polanyi's theory of fictitious labour, the minority report on the Bill stated that:

... If labour is a commodity, it is entirely different from every other commodity, inasmuch as the commodity can never be divorced from the human being - the labourer... [Labour] organizations aim to protect the people against the evils of monopoly not to enhance those evils. ${ }^{70}$

Nevertheless, whilst protecting collective worker action from antitrust attack, this 'statutory labour exemption' did not clarify whether or not antitrust rules would apply to worker organisations when they act jointly with other parties, most notably with employers, to pursue their objectives. This was rather ironic, since collective bargaining in which worker and employer organisations act jointly constitutes one of the most essential functions of a workers' union. As a result, after the Clayton Act, the limits of the so-called non-statutory labour exemption that protects joint actions of worker organisations and third parties from antitrust attack became the most fundamental legal question. ${ }^{71}$

In another case with similar facts to Danbury Hatters, the Supreme Court interpreted the labour exemption narrowly deciding that a secondary boycott with the intention of creating a closed shop for unionised workers could not escape antitrust liability, because it departed from the 'normal or legitimate objectives' of worker organisations. ${ }^{72}$

\footnotetext{
${ }^{64}$ In secondary boycotts unions target not the original employer with whom the workers are in an official conflict but other producers down the production chain who buy goods and services from the original employer. With secondary boycotts unions force producers down the production chain not to buy goods and services from the original employer with the objective of putting extra pressure on the employer to agree to their terms and conditions.

${ }^{65}$ Deitrich Loewe et al $v$ Martin Lawlor et al, (1907) 208 US 274.

${ }^{66}$ Deitrich Loewe, ibid, at 308.

${ }^{67} 15$ US Code $\$ 17 ; 29$ US Code $\$ 52$.

${ }^{68} 15$ US Code $\$ 17$ (emphasis added).

${ }^{69}$ The Senate Report No 698, 63d Congress, 2d Session, at 609.

${ }^{70}$ Minority report on Clayton Act, Section 6, Representatives John M Nelson and AV Volstead, p 2047, cited in Sam Cordova v Bache \& Co, $321 \mathrm{~F}$ Supp 600 (1970) at 611.

${ }^{71}$ See also S Schwochau 'The labor exemptions to antitrust law: an overview' (2000) 21 Journal of Labor Research 535 at 536; RE Lucore 'The fictitious commodity: a union view of labor's antitrust exemption' (2000) 21 Journal of Labor Research 563.

${ }^{72}$ Duplex Printing Press Co v Deering et al, (1920) US 443 at 465
} 
In response to the Court's restrictive readings of the labour exemption, Congress intervened once again with the Norris-La Guardia Act (1932) and the Wagner Act (1935), which extended the scope of legitimate and legal union activity as part of President Roosevelt's New Deal package. The purpose of this legal framework was, inter alia, to protect the collective bargaining process from judicial intervention.

In response, in Hutcheson the Supreme Court decided that the labour exemption not only covered the immediate worker-employer relationship but also secondary boycotts and similar acts as long as the unions acted in their own self-interest and did not combine with non-labour groups. ${ }^{73}$ In the following decades, the Court's interpretation of the labour exemption was not entirely consistent, and was at times considerably restrictive despite the legislative support for collective worker action. The Court's approach became particularly conservative after the political support for collective worker action diminished once President Roosevelt left office and the extensive legal protection provided to collective worker action was partially withdrawn with the Taft-Hartley Act (1947). ${ }^{74}$

In Apex Hosiery the Court decided that a sit-down strike against the employer was not a violation of the Sherman Act, because although 'an elimination of price competition based on differences in labour standards [was] the objective of any labour organisation', this type of restraint had not been shown to have actual or intended effect on price competition. ${ }^{75}$ The Court stated that to be found illegal under the Sherman Act the 'conspiracy and combination must be aimed or directed at the kind of restraint which the Act prohibits', ${ }^{76}$ implicitly recognising the effect on prices as a necessary requisite for the withdrawal of labour exemption. Although the Court did not withdraw the labour exemption in this case, establishing a direct relationship between price competition and the labour exemption did not make legal sense, because actions that do not affect competition do not fall within the scope of the Sherman Act in the first place. Also in the case, the Court explicitly referred to the 'sale of the employee's services to the employer' and the effects of this on price competition against the text and the spirit of the Clayton Act, which declares that the labour of a human is not a commodity. ${ }^{77}$

In Allen Bradley the Court condemned a closed shop agreement imposing a condition on employers to only do business with other employers who are also running a closed shop. According to the Court 'the Congress never intended that Unions could, consistently with the Sherman Act, aid non-labour groups to create business monopolies and to control the marketing of goods and services'. ${ }^{78}$ In the similar case of Pennington, the union considered that in the shadow of the declining coal industry it would be in the workers' best interests if only those employers able to pay higher wages were to stay in the market. Accordingly, the union collaborated with those employers against the sale of nonunion coal. ${ }^{79}$ The Court withdrew the labour exemption in this case, because the restraint on the product market was 'direct and immediate' and of the type 'characteristically deemed unreasonable under the Sherman Act'. ${ }^{80}$ This was followed by the Meat Cutters case in which the Court decided that the union workers' refusal to work at certain times could not be considered a violation of the Sherman Act, emphasising that in this case the union achieved its objective on its own and not in collaboration with others. ${ }^{81}$

In the case of Connell Construction, ${ }^{82}$ following a more conservative approach than previous cases such as Hutcheson, the Court condemned an agreement between the union and a contractor in which

\footnotetext{
${ }^{73}$ United States $v$ Hutcheson, 312 US 219 (1940).

${ }^{74}$ RA Mann et al 'The accommodation between antitrust and labor law: the antitrust law exemption' (1979) 30 Labor Law Journal 295.

${ }^{75}$ Apex Hosiery Co $v$ Leader et al, 310 US 469 (1940) at 504.

${ }^{76}$ Ibid, at 511 .

${ }^{77} \mathrm{Ibid}$, at 503 .

${ }^{78}$ Allen Bradley Co et al $v$ Local Union No 3, 325 US 797 (1945) at 808.

${ }^{79}$ United Workers of America v James Pennington, 381 US 657 (1965).

${ }^{80} \mathrm{Ibid}$, at 663 .

${ }^{81}$ Local Union No 189, Amalgamated Meat Cutters v Jewel Tea Company, Inc, 381 US 674 (1965) (emphasis added).

${ }^{82}$ Connell Construction Company, Inc v Plumbers and Steamfitters Local Union, No 100, 421 US 616 (1974).
} 
the contractor agreed to deal only with mechanical sub-contractors who were party to the union's multi-employer collective bargaining agreement. In this case, the Court did not take into consideration whether the union followed its own legitimate objectives whilst taking collective action with the employer. In his dissent Justice Douglas argued that even if there was a violation in this case, it should be considered a violation not of antitrust law but of federal labour law - which should also therefore provide the remedy. ${ }^{83}$

In the case of USS-Posco, ${ }^{84}$ the federal court came into conflict with the Supreme Court and stated that for the non-statutory labour exemption to be withdrawn the plaintiff needed to prove both the combination of a worker and a non-worker group and an illegitimate purpose in this combination. According to the Court, as long as the union aimed to achieve the traditional objectives of worker organisations normally associated with work-related disputes, it would benefit from the non-statutory labour exemption. ${ }^{85}$ Nevertheless, this more generous formulation received negative treatment in subsequent cases. ${ }^{86}$ As a result, whether or not the union acts with its own legitimate objectives does not constitute an official part of the non-statutory labour exemption and notwithstanding the objectives of the union, if it collaborates with third parties, it will come under the attack of antitrust rules.

\section{(c) Antitrust law against employers in the US}

In the US there is also an antitrust history consisting of cases in which workers attempted to use antitrust rules to challenge collusive employer behaviour aiming to supress wages and other working conditions. This type of employer collusion primarily takes place in markets where highly skilled labour is high in demand but low in supply, resulting in increased worker bargaining power. Nevertheless, as the cases discussed below illustrate, workers have not been particularly successful in utilising antitrust law against collusive employer behaviour.

This is due to two key reasons: first, in cases against employers, federal courts apply the stricter rule of reason test, which requires the proving of adverse effects on competition in the product market and on consumer welfare in the form of, inter alia, increased prices or reduced output, rather than the more lenient per se test which presumes that the type of collusive behaviour in question is more than likely to result in an adverse effect on competition. ${ }^{87}$

Secondly, when evaluating the potential effects on competition, courts at times apply a confusing legal and economic standard looking for increased prices or reduced output in the market for goods and services rather than focusing on the competition in the labour market. Such legal and economic analysis makes little sense because employers are unlikely to increase the prices of their products and services as a result of collusive behaviour reducing labour costs. In fact, reduced labour costs might trigger more competitive prices in the product market notwithstanding the softening or elimination of competition in the labour market. As an incidental effect of applying the consumer welfare test without any acknowledgement of the idiosyncrasy of labour as a fictitious commodity, in many cases courts attempted to establish a relationship between labour costs and competition and prices, and as a result, they treated labour as a commodity against the text and the spirit of the Clayton Act.

For instance, in the case of United Circulation Company, ${ }^{88}$ magazine subscription agencies had entered into a no-hire agreement to make it difficult for workers to switch to an entrant company with the eventual aim of pushing the company out of the market. In this case, whilst acknowledging that the agreement in question might 'freeze labour supply' in the market and discourage worker mobility, the federal court did not investigate how the agreement in question affected workers and

\footnotetext{
${ }^{83}$ Ibid, at 640 .

${ }^{84}$ USS-Posco Industries $v$ County Building \& Construction Trades Council, 31 F3d 800 (9 ${ }^{\text {th }}$ Cir 1994).

${ }^{85}$ Ibid, at 808 .

${ }^{86}$ Waugh Chapel South, LLC v United Food \& Commercial Workers Union Local, 27855 FSupp2d 476, DMd (2012).

${ }^{87}$ See Gavil et al, above n 13, p 259; Polygram Holding Inc v FTC, F3d 29 (DC Cir 2005); Realcomp II, Ltd v FTC, 635 F3d 815 (6th Cir 2011); Standard Oil Company $v$ United States, 221 US 1 (1911).

${ }^{88}$ Union Circulation Company $v$ the Federal Trade Commission, 241 F2d 652 (1957).
} 
the labour market but applied the rule of reason standard to competition between magazine subscription agencies exclusively. As a result, in this analysis, the court treated labour as a commodity in the economic competition between producers. In subsequent cases with similar dynamics, federal courts continued to treat labour as a commodity, as they emphasised the role of worker mobility in the process of competition ${ }^{89}$ and openly discussed the economics of 'selling' and 'buying' of labour, the costs of labour in the industry and the effects of this on competition. ${ }^{90}$

Another legal question facing federal courts that has a fundamental effect on the position of workers in antitrust was whether and to what extent the Clayton Act labour exemption protects collusive employer action from antitrust attack. In Sam Cordova, ${ }^{91}$ brokers working in the stock exchange market accused their employers of colluding to artificially lower the commissions paid to brokers. The federal court rejected the employers' attempt to invoke the labour exemption using particularly political language and stating that section 6 of the Clayton Act aimed at 'preserving labor's right to organise, not that of capital. ${ }^{92}$

Nevertheless, in subsequent cases, federal courts adopted a non-statutory labour exemption that extended to employers against both the text and the spirit of the Clayton Act. In the case of Antony Brown, ${ }^{93}$ the union representing national football players and the National Football League (NFL) reached an impasse in the collective bargaining process with regard to wages paid to junior squad players. The union demanded that players negotiate their salaries individually, whereas the NFL offered a significantly lower flat rate than the players would have secured if they had negotiated individually. When the union rejected the proposal, the teams agreed to unilaterally impose the flat rate notwithstanding the impasse in the collective agreement negotiation. Players sued the teams, arguing that this was a wage-fixing conspiracy in breach of section I of the Sherman Act. In this case, the Supreme Court extended the non-statutory labour exemption established in Connell Construction ${ }^{94}$ to collusive employer behaviour and exempted from the application of federal antitrust laws what would normally constitute a wage-fixing cartel. Mixing antitrust and labour analysis the Court developed an argument which would not stick in either field. According to the Court, 'where its application is necessary to make the statutorily authorized collective bargaining process work as Congress intended, the exemption must apply both to employers and employees'..$^{95}$ In this, the Supreme Court overlooked the fact that the labour exemption was enacted specifically to protect workers from employers and not the other way around. The Court also overlooked that in this case, the employers in question did not aim to contribute to the continuation of the collective bargaining process; rather, they aimed to end it permanently by collectively imposing their individual positions on players.

Wage-fixing agreements between employers are particularly commonplace in industries where highly skilled labour is high in demand but low in supply, which changes the balance of bargaining power to the workers' advantage. Healthcare is one such industry where registered nurse wages constitute the largest sum in the hospitals' cost structure. ${ }^{96}$ There have been a number of cases brought by nurses against hospitals with the allegation of wage-fixing. In those cases, following the rule of reason standard, courts asked the defendants to demonstrate an actual proof of detrimental effect on competition and consumer welfare, such as increased prices or reduced output. ${ }^{97}$ Although defendants

\footnotetext{
${ }^{89}$ Donald F Nichols $v$ Spencer International Press, 371 F2d 332 (1967).

${ }^{90}$ Eichorn $v$ AT \& T Corp, 248 F3d 131 ( $3^{\text {rd }}$ Cir 2001).

${ }^{91}$ Sam Cardova v Bache \& Co, 321 F Supp 600 (1970).

${ }^{92} \mathrm{Ibid}$, at 607 (emphasis added).

${ }^{93}$ Antony Brown v Pro Football, Inc, 518 US 229 (1996).

${ }^{94}$ Connell Construction, above $\mathrm{n} 82$.

${ }^{95}$ Antony Brown, above n 93, at 231.

${ }^{96}$ Wendy Fleischman $v$ Albany Medical Center, 728 F Supp 2d 130 (NDNY 2010) at 162. See also Federal Trade Commission/Department of Justice Joint Statement of Antitrust Policy in Healthcare (1996), available at www.justice.gov/ atr/page/file/1197731/download (16 January 2020).

${ }^{97}$ Wendy Fleischman, ibid, at 162; see also Pat Cason-Merenda v Detroit Center, 862 FSupp2d 603 (ED Mich 2012).
} 
proved the existence of a complex communication network allowing hospitals to share information on existing and future wages, courts were not convinced that information exchange alone would reduce the incentives of hospitals to offer competitive wages to their employees and subsequently to reduce competition. $^{98}$

High-Tech Employee Antitrust Litigation ${ }^{99}$ remains the only case in which workers successfully proved the existence of a cartel between employers constituting a per se violation of federal antitrust rules. In a case involving several American national champions, which surprisingly attracted little coverage in the international media, multinational corporations of the Silicon Valley, including Adobe, Apple, Google, Intel, Lucasfilm and Pixar Film, entered into a network of bilateral agreements under the leadership of the late Steve Jobs, who was either a member of or influential in the management boards of these companies. The purpose of these agreements was to prevent those companies from approaching each other's employees with the aim of hiring them. The agreements formed 'an overall conspiracy that resulted in artificially lower salaries' in the industry. ${ }^{100}$ In a substantially different move from other similar cases, the US Department of Justice had previously investigated the same network of agreements as a per se violation of the federal antitrust law ${ }^{101}$ and the evidence collected during this investigation provided the main factual framework of the plaintiffs' case. Arguably this made it relatively easier for the plaintiffs to prove the existence of a per se violation in this case.

\section{(d) A comparison and summary of the EU and US legal positions}

Courts on either side of the Atlantic apply different legal tests with the aim of solving the competitionsolidarity conflict. Nevertheless, despite the differences in the legal tests applied, it can safely be argued that competition laws have become a disciplining mechanism against collective worker action both in the EU and the US.

In the EU, the competition-solidarity conflict is resolved by taking as reference points the objectives of the Union as specified in the founding Treaties as well as the characteristics of undertakings as defined in EU competition law. The result is a fragile judge-made labour exemption based on a limited and imprecise definition of the collective bargaining process as well as an abundant emphasis on employer control. This tightly framed judicial exemption is likely to impede collective action, particularly by casualised workers, who are kept at legal arms' length by employers, which is becoming an increasingly common type of work rather than the exception.

Workers receive even more drastic treatment in US antitrust law, which has practically become a device to discipline workers and to prevent collective action. As the US antitrust laws potentially apply to all individuals, Congress had to step in and adopt a labour exemption in order to protect collective worker action from antitrust attack. Nevertheless, the Supreme Court adopted a restrictive judicial test to apply this exemption, even in the presence of strong legislative support for collective action. Federal courts treat labour as a commodity in antitrust cases despite the characteristics of labour as a fictitious commodity, which was explicitly recognised in the Clayton Act. In this, courts explicitly conflict with the text and the spirit of federal antitrust law by overlooking the fact that unlike other production factors, labour is attached to and inseparable from the human.

Ironically, courts also extend the labour exemption to shield collective employer action from antitrust attack - against the explicit intention of Congress to protect workers and not employers. It can be clearly seen in Congress debates that the legislature was aware of the idiosyncrasies of labour, which make it particularly open to exploitation, whilst enacting the Clayton Act.

\footnotetext{
${ }^{98}$ Wendy Fleischman, above n 96; Pat Cason-Merenda, ibid, at 646.

${ }^{99} 856$ FSupp 2d 1103 (ND Cal 2012).

${ }^{100}$ Ibid, at 1117 .

${ }^{101}$ However, surprisingly, the Department of Justice in this case did not seek any criminal remedies, arguably for political reasons given that the defendants were national champions in the global technology market. See S Vaheesan 'Accommodating capital and policing labor: antitrust in the two gilded ages' (2019) 78 Maryland Law Review 766.
} 
Additionally, in the US, antitrust law has become a double-edged sword in conflicts between employers and workers. Whilst removing the labour exemption easily in cases brought by employers against collective worker action, courts apply strict and confusing legal standards in cases brought by workers against employers. Federal courts consistently classify collusive employer behaviour against workers as a potential antitrust violation under the rule of reason, rather than the per se, category. This makes it technically difficult and extremely costly for workers to prove employer conspiracies against federal antitrust law. In light of the rule of reason standard, workers will have to show an effect on competition in the product market to prove anti-competitive behaviour. This makes only a little legal and economic sense, because anti-competitive behaviour supressing wages and other working conditions is unlikely to result in a negative effect on consumer welfare in the product market, in the form of, inter alia, increased prices or reduced output. As a result, it is not surprising that workers have not been successful in invoking antitrust rules against collusive employer behaviour in all cases but one.

\section{The competition-solidarity conflict in light of labour exploitation theory: moving from consumer to citizen welfare}

Economic models from opposing ends of the political spectrum perceive labour as a special and different production factor with idiosyncratic qualities, which makes it particularly open to exploitation. Labour's particular likelihood for exploitation is all the more worrying because labour power is attached to and cannot be separated from the worker. Additionally in the case of labour, unlike other production factors, there is not a zero-sum dynamic between the value attached to the production factor and consumer welfare. This is because, as exemplified in Marx's labour fetish theory, most consumers are also workers. As a result, when wages increase this benefits consumers in their economic role as workers even though they might have to pay a higher price for products and services.

As a result, economic theory suggests that, unlike commodities and other production factors, conflicts involving labour cannot be solved using simple economic cost-benefit analyses without any substantial adjustment. Similarly, worker solidarity and collective action need protection as common goods when they come into conflict with the principle of competition not only because this would be socially just but also because it would be economically sound.

As the analysis in the previous section illustrates, competition rules in the EU and the US are applied with a strict consumer welfare standard in mind, which overlooks the idiosyncratic characteristics of labour, and as a result, competition rules become a disciplining mechanism against collective worker action. Consequently, when dealing with the competition-solidarity conflict, courts and competition authorities need to follow a more inclusive legal standard that better reflects the characteristics of labour as a production factor. For this purpose, this paper suggests a citizen (rather than consumer) welfare standard that takes into consideration the economic effects of anti-competitive behaviour on consumers as well as workers. The citizen welfare standard could also be applied in other cases where competition rules and principles come into conflict with public interest or other policy objectives, such as cases involving industrial policy, environmental policy or other social objectives in which competition authorities and courts are yet to produce a consistent approach. ${ }^{102}$ As a result, in these cases, competition authorities and courts would be able to look at how the specific behaviour in question affects citizens in their entirety as a holistic group, rather than focusing on the interests of the narrow category of consumers.

Another significant advantage of following this approach is that this would not require a change in the law but only a change in the approach and the legal tests employed by courts and competition authorities when they deal with the competition-solidarity conflict.

In light of the citizen welfare standard, collective worker action would be shielded from competition law attack under labour exemption, because even though collective worker action could result in

\footnotetext{
${ }^{102}$ See Witt, above n 9.
} 
increased prices in the product market due to higher labour costs and decreased consumer welfare, it would also increase the welfare of workers, who will benefit from increased wages and better working conditions. An exemption standard that is based on an inclusive welfare approach will also save courts and competition authorities from disentangling who qualifies as an undertaking (in the EU) and whether or not worker organisations acted jointly with third parties (in the US), both of which result in imprecise and limited judicial exemptions that do not provide a secure harbour for collective worker action and render it particularly precarious for workers in casualised flexible arrangements to take collective action against their working conditions.

Similarly, in light of the citizen welfare standard, even if the effect of collusive employer behaviour on prices in the product market cannot be proven, a reduction in the welfare of workers in the production process, such as reduced wages, will be considered sufficient for the collusion in question to qualify as anti-competitive. Collusion between employers suppressing wages and other working conditions does not necessarily affect consumer welfare. Suppression of wages might even result in reduced prices and increased consumer welfare due to reduced labour costs in the short run but this comes at the cost of a negative effect on worker welfare.

This does not mean that courts should engage in a balancing analysis between consumer and worker welfare and investigate whether the effect on consumer or worker welfare is larger. In the light of the labour fetish theory, consumers and workers belong to the same group of people and an increase/decrease in consumer welfare with the resulting decrease/increase in worker welfare is most likely to be a transfer. Under the citizen welfare standard, an increase in worker welfare would be considered sufficient for the labour exemption to protect collective worker action from antitrust attack and a decrease in worker welfare would be considered sufficient for the employer collusion in question to be considered anti-competitive.

The citizen welfare approach would also reflect the complexity of the modern economic and social life in which individuals have multiple overlapping roles and identities, such as workers and consumers. A strict consumer welfare standard, as is currently applied, does not reflect this complexity and compartmentalises an individual's economic and social roles.

This paper does not argue that competition law on its own can solve the problem of wage inequality. This is not competition law's objective and neither is it equipped with the means to achieve it. Investigating the competition law-equality relationship requires more extensive law and economics analysis, which is beyond the scope of this paper. Nevertheless, in the context of the competitionsolidarity conflict, competition law would be more likely to contribute to equality - or at least not to contribute to inequality - under the citizen welfare standard. The competition-equality debate overlooks the production process that goods and services go through before they meet consumers, as well as the role of workers within it. Workers and individuals within the 'reserve army' of precariousness have felt the effects of the 2008 crisis the worst. ${ }^{103}$ A competition law that does not pay attention to the idiosyncrasies of labour is likely to contribute towards inequality facing workers and precariously employed individuals. As shown in this paper, competition law in terms of the consumer welfare standard has become a double-edged sword - disciplining collective worker action, arguably at a time when there is utmost need for it, whilst treating collusive employer behaviour leniently. The citizen welfare standard suggested in this paper would prevent competition law from being strategically used to prevent effective collective worker action. In other words, the citizen welfare standard would prevent competition rules from jeopardising workers' collective action in search of equality. Similarly, competition rules applied under a citizen welfare standard would prevent employers from suppressing wages and other working conditions, particularly in markets in which the bargaining power tilts in the workers' favour. As a result, in those situations competition law would prevent employers from interfering with the distribution of wealth to their own benefit and to the workers' detriment.

\footnotetext{
${ }^{103} \mathrm{JB}$ Foster et al 'Monopoly and competition in twenty-first century capitalism' (2011) 62 Monthly Review, available at https://monthlyreview.org/2011/04/01/monopoly-and-competition-in-twenty-first-century-capitalism/ (last accessed 27 July 2020).
} 


\section{Conclusions}

The conflict between market competition and worker solidarity attracts significant public and scholarly attention due to the conundrum of gig workers, who potentially face competition law attack when attempting to take collective action against their working conditions. This paper investigated the more fundamental question of how competition law approaches the competition-solidarity conflict beyond the limited case of the gig economy on both sides of the Atlantic. Diverging from the mainstream competition law scholarship, this paper conducted this analysis from the perspective of an original holistic theoretical framework bringing together Marxian and neoclassical labour exploitation theories.

This investigation revealed that, under the consumer welfare standard, competition law has become a disciplining mechanism against collective worker action. This is because the consumer welfare standard overlooks the idiosyncratic characteristics of labour, which render labour different to other production factors and particularly prone to exploitation. As an alternative, the paper offers an inclusive citizen welfare standard that better reflects the qualities of labour.

The citizen welfare standard takes into consideration the economic production as well as the exchange process and acknowledges that individuals have multiple roles and identities as workers as well as consumers. By adhering to this standard, competition law would be prevented from targeting collective worker action increasing workers' welfare even though this might come with the cost of reduced consumer welfare. Similarly, under the citizen welfare standard, competition law would target employer collusion resulting in reduced worker welfare, even though this might increase consumer welfare in the short run.

This paper also informs the post-2008 competition-equality debate that overlooks the production process underlying exchange relationships and the role of workers within it. When applied in light of the citizen welfare standard, competition law cannot be used strategically to jeopardise collective worker action in search of equality. Similarly, when applied in light of the citizen welfare standard, competition law would prevent employers from interfering with the distribution of wealth to their own benefit. As a result, in light of the citizen welfare standard, competition law would be more likely to contribute to equality - or at least less likely to contribute to inequality.

Cite this article: Cengiz F (2021). The conflict between market competition and worker solidarity: moving from consumer to a citizen welfare standard in competition law. Legal Studies 41, 73-90. https://doi.org/10.1017/lst.2020.31 